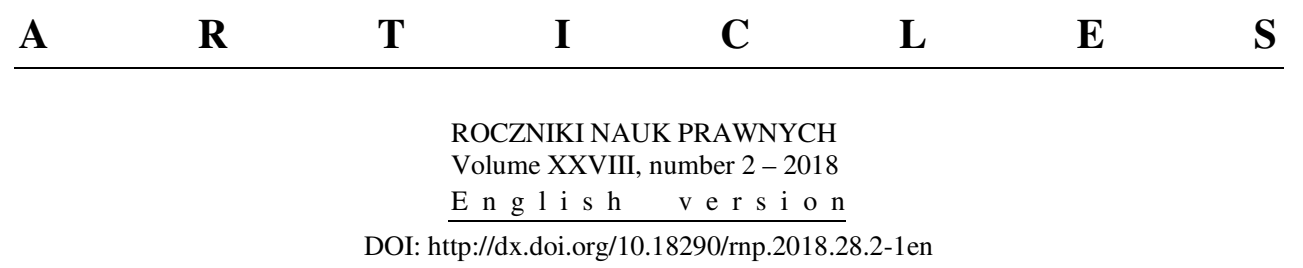

ANNA FERMUS-BOBOWIEC

\author{
MUNICIPAL MORTGAGE LOAN INSTITUTIONS \\ IN THE KINGDOM OF POLAND. A CONTRIBUTION \\ TO THE DISCUSSION ON THE ORGANISATIOAL MODEL \\ OF MORTGAGE CREDIT IN POLAND
}

\title{
INTRODUCTORY NOTES
}

2017 marked the twentieth anniversary of the adoption of the Act of 29 August 1997 on covered bonds and mortgage banks, ${ }^{1}$ which laid down the legal foundations for mortgage banks in the Third Polish Republic. This anniversary may provide an excellent opportunity to sum up the development of long-term mortgage loan institutions in Poland, which, as Professor Marek Wąsowicz stressed, have had "a long and beautiful tradition."

This is due to the fact that long-term credit, based on a solid mortgage system and implementing the principles of openness and detail, authorised on the Polish soil already by the Constitution of 1588 , a law which anticipated the regulations implemented in other European countries by more than two centuries. ${ }^{3}$ Mortgage played (and continues to play) a key role in the

Anna Fermus-Bobowiec, PhD, is an assistant professor at the Department of History of State and Law, Institute of History and Theory of State and Law, Faculty of Law and Administration, Maria Curie-Skłodowska University in Lublin (UMCS); address: Plac Marii Curie Skłodowskiej 5, 20-031 Lublin, Poland; e-mail: fermus@wp.pl

${ }^{1}$ Journal of Laws No. 140, item 940; the applicable consolidated text is available in the Journal of Laws of 2016, item 1771 [hereinafter referred to as ACBMB].

${ }^{2}$ A. PietrasiK and A. LASKOwsKi, Historia i wspótczesność długoterminowego kredytu hipotecznego w Polsce (Warszawa: Wydawnictwo Twigger, 2001), 11.

${ }^{3}$ B. RAKOwIECKI, "Stulecie Ustawy sejmowej Hipotecznej 1818 r.," Gazeta Sadowa Warszawska 30 (1918): 288; O. BALZER, "Hipoteka w dawnym ustawodawstwie polskim," Gazeta 
activities of long-term credit institutions, whose functioning is possible only when a well-developed mortgage system is in place. In this regard, special attention should be paid to the mortgage law of the Polish Kingdom enacted in 1818 and supplemented in $1825,{ }^{4}$ presenting high-quality legislationmaking it the best regulation of this kind in Europe at that time, and bringing honour to our jurisprudence. ${ }^{5}$

Long-term lending institutions would therefore be established in the Polish Kingdom and in the annexed Polish territories ${ }^{6}$ from the nineteenth century onwards, as part of initiatives aimed at ensuring the economic survival of these lands and a prosperous material existence, despite the existing political circumstances. ${ }^{7}$ They were present in the reality of the Second Republic, disappearing later in the period of the Polish Peopleą's Republic, where in the conditions of a centrally controlled economy, the task of satisfying housing needs, including the financing of construction industry, was assigned to the State. ${ }^{8}$ With this assumption, institutions granting long-term loans were dissolved under the reform of the banking system. ${ }^{9}$

Sądowa Warszawska 29 (1888): 480-81; A. GĄSOwSKA, Bankowość hipoteczna (Warszawa: Poltext, 2000): 119.

${ }^{4}$ Act on determination of the ownership of immovable property, privileges and mortgage in place of Title XVIII of Book III of the Civil Code of 14/26 April 1818, Dziennik Praw Królestwa Polskiego [hereafter Dziennik Praw] of 1817, No. 21, pp. 293-387 (the so-called large property mortgage), supplemented by the Law on privileges and mortgages of 1/13 June 1825, Dziennik Praw of 1825, No. 40 , pp. 355-373, which also covered smaller property by the mortgage regulation.

${ }^{5}$ W. Wóscikiewicz, Prawo hipoteczne Królestwa Polskiego (Wrocław-Warszawa-Kraków: Zakład Narodowy im. Ossolińskich, 1967), 63.

${ }^{6}$ They relied on the mortgage models used in the Prussian and Austrian partitions-for more on that, see K. Józefowicz, Przepisy o hipotekach, czyli wykład prawa hipotecznego w Królestwie Polski obowiazujacych (Warszawa: Druk Orgelbranda synów, 1873), 6-28; K. Hube, O instytucji hipotecznej w Królestwie Polskim (Warszawa: Drukarnia Gazety Polskiej, 1869), 2-40; WósCIKIEWICZ, Prawo hipoteczne, 25-34.

${ }^{7}$ A. Korobowicz and W. WitKowsKi, Historia ustroju i prawa polskiego (1772-1918) (Warszawa: Wolters Kluwer Polska, 2012), 85-86.

${ }^{8}$ In the Polish People's Republic, housing needs could essentially be satisfied by the socalled kwaterunek [administrative, forced lodging - Translator's note], under which accommodation was allocated by an administrative decision, without the owner's participation, whose right to dispose of the residential premises was excluded in this respect. Administrative and legal control also covered the terms of use of residential premises, including determination of rents, and a strong protection of the tenant against termination of their tenancy relationship. Rents were subject to control under the law and their rates were almost symbolic. In this way, administrative-law forms of allocation and the use of dwellings provided the solution to the housing problem. Thus, the mortgage loan market, which would otherwise finance the acquisition of real estate ownership, did not exist. For more on this, see A. Fermus-Bobowiec, "Problem 'kwaterunku' lokali mieszkalnych w ustawodawstwie i nauce Polski Ludowej," Zeszyty Naukowe Uniwersytetu 
However, due to the lending tradition going back to the nineteenth century we can talk about a restoration of long-term credit institutions in Poland in 1997 rather than their birth.

In turn, the twentieth anniversary of the adoption of the act on covered bonds and mortgage banks calls for a reflection on the future of mortgage banking in Poland. This segment of the financial system is developing slowly and the mortgage loan market remains dominated by universal banks. Since January 1, 1998, that is the entry into force of the said act (Article 42 of the AMBMB), there have been two or three mortgage banks. It was not until 2015 that PKO Bank Hipoteczny (former BRE Bank Hipoteczny), Pekao Bank Hipoteczny (former HypoVereinsbank Bank Hipoteczny, and later BPH Bank Hipoteczny) was established alongside the existing mBank Hipoteczny (former BRE Bank Hipoteczny). ${ }^{10}$ This trend has changed slightly over the last two years, when the Banking Supervision Commission has been receiving further applications for the creation of mortgage banks (Raiffeisen Polbank and Getin Noble Bank, ${ }^{11}$ most recently also ING Bank Śląski ${ }^{12}$ ), and the sale and issue of covered bonds has been increasing. It turns out that there is a significant demand for these financial instruments in

Przyrodniczo-Humanistycznego w Siedlcach 31 (2015): 49-70; IDEM, "Z problematyki najmu lokali mieszkalnych w Polsce Ludowej," Z Dziejów Prawa 7 (2014): 257-78.

${ }^{9}$ R. PAPIEŻ, Bankowość hipoteczna w Polsce (Kraków: Oficyna Wydawnicza Text, 2004), 52. The dissolution was regulated by the following normative acts: Decree of 25 October 1948 on the rules and procedure for dissolving certain banking enterprises, Journal of Laws No. 52, item 410; Decree of 25 October 1948 on the rules and procedure for dissolving certain long-term loan institutions, Journal of Laws No. 52, item 411; Decree of 25 October 1948 on bank reform, Journal of Laws No. 36, item 279.

${ }^{10}$ R. PAPIEŻ, "Bankowość hipoteczna w Polsce. Czy wreszcie ruszy z miejsca?" accessed June 25, 2017, https://rynekpierwotny.pl/wiadomosci-mieszkaniowe/bankowosc-hipoteczna-wpolsce-czy-wreszcie-ruszy-z-miejsca/3528. The first Polish mortgage banks, namely BRE Bank Hipoteczny (initially called RHEINHYP-BRE Bank Hipoteczny) and HypoVereinsbank, started operating in 1999. In 2001, they were joined by Śląski Bank Hipoteczny. HypoVereinsbank Bank Hipoteczny was owned by BPH PBK Bank, and in the process of merging its structures with Bank Pekao SA, it changed its name and since 31 July 2008 it has been operating as Pekao Bank Hipoteczny S.A. The owner of Śląski Bank Hipoteczny (later: ING Bank Hipoteczny S.A.) was ING BSK (later: ING Bank Śląski S.A.). In turn, ING Bank Hipoteczny S.A. was absorbed by ING Bank Śląski S.A. on 31 October 2011-Raport z prac Grupy ds. emisji listów zastawnych przez banki, published by Office of the Banking Supervision Commission in 2013 [later merged with Financial Supervision Authority, KNF — Translator's note], p. 16.

${ }^{11}$ P. Sobolewski, “To już piąty bank hipoteczny w Polsce," accessed June 25, 2017, http://www.rp.pl/artykul/ 1193183-To-juz-piaty-bank-hipoteczny-w-Polsce.html\#ap-1.

${ }^{12}$ [NO AUTHOR], "ING Bank Śląski złożył do KNF wniosek ws. utworzenia banku hipotecznego,” accessed June 25, 2017, http://biznes.onet.pl/gielda/wiadomosci/ing-bank-slaski-zlozyldo-knf-wniosek-ws-utworzenia-banku-hipotecznego/m3j7ml. 
Poland. In the second quarter of 2016, Polish covered bonds worth 1.15 billion PLN were purchased, which has been the best quarter in history. ${ }^{13}$ Is it possible that the renaissance of the Polish mortgage banking has just begun?

\section{LONG-TERM CREDIT INSTITUTIONS ON THE POLISH SOIL}

In present-day Poland, mortgage credit remain basically in the domain of universal banks. ${ }^{14}$ In the nineteenth century, however, mortgage loans were granted by specialised, long-term credit institutions, whose goal was to provide loans secured by mortgage on real estate. These institutions operated in two organisational models: credit societies and mortgage banks. ${ }^{15}$

Credit societies appeared in Poland as early as the first half of the $19^{\text {th }}$ century and were modelled on Śląskie Towarzystwo Kredytowe Ziemskie [Silesian Land Credit Society], established in Wrocław and covering the entire province of Silesia in 1769, according to the concept of the Prussian Minister of Justice, Baron Johann von Carmer. ${ }^{16}$

The first land credit society, derived from the Prussian Landschaft, was Towarzystwo Kredytowe Ziemskie dla Wielkiego Księstwa Poznańskiego [Land Credit Society of the Grand Duchy of Poznań], established in 1821; the second, but of fundamental importance in the history of long-term credit development was Towarzystwo Kredytowe Ziemskie [Land Credit Society], established in 1825 in the Kingdom of Poland. Moreover, in 1841 Galicyjski Stanowy Instytut Kredytowy was established in the province of Galicia, which from 1869 operated under the name of Galicyjskie Towarzystwo Kredytowe Ziemskie [Galician Land Credit Society]. ${ }^{17}$

\footnotetext{
${ }^{13}$ M. RUDKE, "Polski rynek listów zastawnych urośnie,” Rzeczpospolita, November 11, 2016, accessed June 25, 2017, http://www.rp.pl/Wywiady/311079886-Polski-rynek-listow-zastawnychurosnie.html\#ap-1.

${ }^{14}$ Z. DoBosiEwicz, Kredyty i gwarancje bankowe (Warszawa: Polskie Wydawnictwo Ekonomiczne, 2007), 119.

${ }^{15}$ M. WĄSOWICZ, "Instytucje kredytu długoterminowego na ziemiach polskich: rozwiązania rodzime, czy recepcja obcych wzorów?" in Wielokulturowość Polskiego Pogranicza. LudzieIdee-Prawo, ed. A. Lityński and P. Fiedorczyk (Białystok: Wydawnictwo Uniwersytetu w Białymstoku, 2003), 94.

${ }^{16}$ Ibid., 96-97 K. KANIGOWSKI, Bank hipoteczny a rynek nieruchomości (Warszawa: Twigger, 2001), 15-21.

${ }^{17}$ WĄSOWICZ, Instytucje kredytu dtugoterminowego, 97-98; F.A. ZuBELEWICZ, O papierach publicznych w ogólności ze szczegótowym opisem papierów krajowych, ważniejszych zagranicznych $i$ instytucji, które na ich handel wptywaja (Warszawa: druk przy ul Rymarskiej, 1843), 399, 294, 199-200. For more on the subject of Towarzystwo Kredytowe Ziemskie w Królestwie
} 
The organizational model of land-based credit unions was then used in the municipal credit unions established in Poland, especially in the Kingdom of Poland, starting in 1870. It was in 1870 that the first Towarzystwo Kredytowe miasta Warszawy [Warsaw Municipal Credit Society] was established. ${ }^{18}$ The next was Towarzystwo Kredytowe miasta Łodzi [Łódź Municipal Credit Society] (1872), and then other societies were established for the following cities: Lublin (1885), Kalisz (1885), Płock (1886), Piotrków (1895), Radom (1898), Łomża (1898), Kielce (1898), Częstochowa (1898), Siedlce (1898), and Suwałki (1899). ${ }^{19}$

In the latter half of the nineteenth century, apart from land and municipal loan societies, another group of long-term lending institutions began to appear, namely mortgage banks, ${ }^{20}$ the establishment of which was initiated by the creation in 1852 of a mortgage bank in France, Crédit Foncier de France, on the initiative of a Polish emigrant, economist and lawyer, Ludwik Wołowski. ${ }^{21}$

In the Polish territory, the first mortgage bank was Cesarsko-Królewski Uprzywilejowany Galicyjski Akcyjny Bank Hipoteczny SA [Imperial-Royal Privileged Galician Mortgage Bank SA], established in 1867. Under the Russian rule, Wileński Bank Ziemski SA. [Vilnius Land Bank SA] was established in 1872. Mortgage banking developed less dynamically in the Prussian Partition because the banks established there were not mortgage banks in the strict sense, but banks offering a wider range of services (all banking operations). ${ }^{22}$

In the era of the Partitions, therefore, it was the land and municipal credit societies that were the chief long-term lending institutions in Poland, for the development of mortgage banks will occur only in the times of the Second Polish Republic. ${ }^{23}$

Polskim, see S. ZALEWSKI, Ewolucja kredytu dtugoterminowego ziemskiego w Polsce (Warszawa: Instytut Wydawniczy „Biblioteka Polska”, 1938), 35-53.

${ }^{18}$ The charter of the Warszawa Municipal Loan Society was approved by the Emperor on 31 December 1969 / 12 January 1870, Dziennik Praw of 1870, No. 240, pp. 5-61.

${ }^{19}$ The indicated dates of establishing municipal loan societies are the dates of approval of their charter-A. BARDzKi, Towarzystwa Kredytowe Miejskie, cz. I. Powstanie i rozwój (Warszawa: Druk Noskowskiego, 1912), 14, 422, 472, 517, 544, 584, 603, 613, 631, 643, 663.

${ }^{20}$ KANIGOWSKI, Bank hipoteczny, 39-41.

${ }^{21}$ Wąsowicz, Instytucje kredytu dtugoterminowego, 99; R.W. KASZUBSKI and M. OLSZAK, Bank hipoteczny. Zagadnienia prawne (Warszawa: Difin 2000), 17.

${ }^{22}$ WĄSOWICZ, Instytucje kredytu dtugoterminowego, 100-101; PIETRASIK and LASKOWSKI, Historia i wspótczesność, 156-58.

${ }^{23}$ WĄSOWICZ, Instytucje kredytu dtugoterminowego, 101-2; see in more detail in KANIGOWSKI, Bank hipoteczny, 45-57; PIETRASIK and LASKOWSKI, Historia i wspótczesność, 145-72. 
The whole panorama of these institutions can be seen in the Kingdom of Poland, where the Towarzystwo Kredytowe Ziemskie 1825, and in the years 1870-1899 twelve municipal credit societies were established. ${ }^{24}$ These institutions adopted the same credit mechanism, whose details of functioning obviously differed without affecting the adopted model. The main difference lay in the adopted institutional model-Towarzystwo Kredytowe Ziemskie, which offered mortgage loans to landowners, covered the entire Kingdom of Poland; municipal credit societies, in turn, were established separately for individual cities of the Kingdom of Poland. ${ }^{25}$

The long-term credit model offered by credit societies was based on the solutions used by Prussian Landschafts. The societies were associations of indebted land or city property owners whose aim was to grant long-term loans secured mainly by mortgage. Mortgage collateral for loans granted by the societies was the basis for the issue of covered bonds as securities issued by the societies which granted the loans and which were used by borrowers to repay their existing creditors in order to place the society first in the mortgage. In this way, the real estate was cleared-the existing and secured mortgage loans were replaced by a loan from the society, which was used to pay off the existing debts. Covered bonds, on the other hand, as securities, were in circulation and had a market value, higher or lower than the face value. The society accepted from its debtors instalment payments of loans together with interest, and the cash obtained in this way was used to pay out interest to the owners of covered bonds and to redeem them at their nominal value, according to the value of redeemed (repaid) loans. ${ }^{26}$

\section{MUNICIPAL CREDIT SOCIETIES AS ILLUSTRATED BY THE LUBLIN MUNICIPAL CREDIT SOCIETY}

A typical institution granting municipal long-term credit, representative of credit societies in general and of municipal credit societies in particular, was Lubelskie Towarzystwo Kredytowe Miejskie, whose charter was

\footnotetext{
${ }^{24}$ For more on the establishment of municipal credit societies in the Kingdom of Poland, see A. Fermus-Bobowiec, Towarzystwo Kredytowe miasta Lublina (1885-1915) (Lublin: Wydawnictwo Uniwersytetu Marii Curie-Skłodowskiej, 2010), 29-37.

${ }^{25}$ Pietrasik and LASKOWSKI, Historia i wspótczesność, 68; WąsOwiCZ, Instytucje kredytu dtugoterminowego, 100.

${ }^{26}$ KANIGOWSKI, Bank hipoteczny, 21-28, 32-35; A. PIETRASIK and R. RYKOwSKI, Hipoteczny list zastawny (Kraków: Kantor Wydawniczy Zakamycze, 2000), 22-23.
} 
approved by the Minister of Finance on June $25 /$ July $7,1885 .{ }^{27}$ On the one hand, the adopted lending mechanism clearly referred to solutions typical of land credit societies, including Towarzystwo Kredytowe Ziemskie; on the other hand, the charters of municipal credit societies were almost identical, differing only in solutions of marginal importance from the point of view of their legal status, resulting from different urbanisation and economic conditions in which they were applied. ${ }^{28}$

Municipal credit societies were established in the Kingdom of Poland with a view to granting loans secured by mortgages on municipal real property. These loans were not in cash but were granted in the form of covered bonds - securities issued by these societies. ${ }^{29}$

The societies were therefore typical institutions of long-term loans granted to owners of city real estate for the purpose of mortgage security on such estate. At the same time, they fulfilled the role of debt relief for city property owners by providing long-term, low-interest loans instead of shortterm, high-interest loans previously available on the market. The loan granted by such a society had to be repaid by the existing creditors so that the society's claim on the loan could take the first place in the mortgage order as absolutely required by its charter $(\S 9, \S 28$ of the LTKM Charter, pp. 233, 235, 243).

At the same time, the loan offer of municipal credit societies was very attractive, as illustrated by information concerning Lublin. The creation of the Lublin Municipal Credit Society resulted in a drop in mortgage interest rates by $40-50 \%$.

For 35 years, LTKM granted loans ( $\$ 13$ of the LTKM Charter, p. 235) bearing interest of $6 \%$ per annum, and 5\% since 1893 ( $\$ 11$ of the Charter, p. 235) ${ }^{30}$ By the time the Society was established, the mortgage interest rate had reached $10 \%$ per annum and loans at $9 \%$ could be negotiated for premises with the best location. ${ }^{31}$

\footnotetext{
${ }^{27}$ PIETRASIK and LASKOwsKi, Historia i wspótczesność, 75.

${ }^{28}$ Fermus-BoBowIEC, Towarzystwo Kredytowe miasta Lublina, 35-36.

${ }^{29} \S 1$ of the charter of Lubelskie Towarzystwo Kredytowe Miejskie of 25 June / 7 July 1885, in Zbiór Praw. Postanowienia i rozporządzenia rządu w guberniach Królestwa Polskiego obowiazujące, wydane po zniesieniu w 1871 r. urzędowego wydania Dziennika Praw Królestwa Polskiego, vol. 29, part 3, p. 229 [hereinafter referred to as LTKM Charter].

${ }^{30} \S 11$, following the amendment by Sobranije Uzakonienij i Rasporiazhenij Prawitelstwa izdawajemoje pri Prawitelstwujuszczem Senatie of 1893, No. 60, Part 1, p. 525.

${ }^{31}$ W. KARWOwSKI, "Towarzystwo Kredytowe miasta Lublina," in Dla sierot. Ksią̇ka zbiorowa wydana staraniem Lubelskiego Towarzystwa Dobroczynności (Warszawa 1897), 80-81.
} 
The interest rate on loans from credit societies remained at similar levels in other cities of the Kingdom of Poland. In Warsaw and Łódź, loans were given with an annual interest of 5\% as originally stipulated in the original charter, inducing those companies which offered loans at a higher rate $(6 \%)$ to take measures to reduce the interest rate. This concerned, among others, the cities of Lublin, Kalisz and Płock. After 1896, the Warsaw and Łódź Municipal Credit Societies reduced their interest rate to $4.5 \%$. Ultimately, the interest rate on loans from municipal credit societies remained at the level of $5 \%$ and $4.5 \%$ throughout the Kingdom of Poland. ${ }^{32}$

On the other hand, receivables from loans granted of municipal credit societies, secured by mortgages on real estate, constituted the basis for the issue of covered bonds in which these loans were granted ( $\$ 35$ of LTKM Charter, p. 247). Covered bonds, on the other hand, were traded securities, so they had a specific face and market value. ${ }^{33}$ The societies were obliged to pay the interest specified by the bonds to their owners and to buy them back at specified dates at their nominal price ( $\$ 32$ of the Charter, p. 245).

Each society was therefore, on the one hand, a lender/creditor to borrowers and property owners, and, on the other hand, a debtor to covered bond holders for the obligation embodied therein to pay interest and purchase bonds at their nominal value. The society therefore acted as an "intermediary" accepting the repayment of the loans and their interest, from which in turn it derived funds to satisfy the owners of the covered bonds. ${ }^{34}$

Thus, the Unions were non-profit institutions, self-financing associations of debtors, with no own capital. The purpose of their activity was to reduce the debt of municipal (land) ownership and to inject capital to the market in order to enable further investments.

The scope of such lending activity testifies to the success of municipal credit societies, which were accurately described as the victorious conspiracy of bankrupts. ${ }^{35}$ The strongest institution among them was Towarzystwo Kredytowe Miasta Warszawy, which already in its first year of operation

\footnotetext{
${ }^{32}$ A. BARDZKI, Towarzystwa Kredytowe Miejskie, cz. II. Ustawa (Warszawa: Druk Noskowskiego, 1911), 48.

${ }^{33}$ The face value of the covered bonds was equal to their denomination, but the real value was influenced by the market, i.e. the price of the covered bonds traded on the Warszawa Stock Exchange. On the nominal and stock exchange value of Lublin covered bonds, see FERMUS-BoBowIEC, Towarzystwo Kredytowe miasta Lublina, 251-54.

${ }^{34}$ Ibid., 234.

${ }^{35}$ S. BRATKOWSKI, "Zwycięski spisek bankrutów," Wiedza i Życie 9 (1996), accessed June 27, 2017, http:// archiwum.wiz.pl/1996/96092400.asp.
} 
(1870/1871) granted loans for the amount of $4,138,800$ roubles ${ }^{36}$ which resulted from the fact that Warsaw was the largest urban centre of the Kingdom of Poland. ${ }^{37}$ In 1914, in turn, the amount of unredeemed loans in the Warsaw Society reached approximately $149,600,000$ roubles, which gave it a share of $65.8 \%$ in the total amount of unredeemed loans granted by all municipal credit societies. ${ }^{38}$ The second largest was Towarzystwo Kredytowe Miasta Łodzi, the industrial capital of the Kingdom of Poland, where the amount of loans granted in the first year of the Society's operation reached $1,000,000$ roubles, amounting to $20,000,000$ roubles at the end of the nineteenth century, and 45,000,000 roubles in 1914. The next in rank was the society in Piotrków with a sum of unredeemed loans amounting to nearly $10,000,000$ roubles in 1914, followed by the Częstochowa Society, where the size of the lending activity stemmed from the general urban development of the city, which at that time was an important industrial and trading centre. Next, there was the Lublin Society with the amount of unredeemed loans reaching in 1914 over 4,000,000 roubles, thus overtaking other municipal credit societies in Kalisz and Płock, where the respective sum reached 3,000,000 roubles, Łomża, Radom, Siedlce and Suwałki, where it was between 1,000,000 and 2,000,0000, and Kielce, where it did not even reach $1,000,000$ roubles. ${ }^{39}$

\section{CONCLUSION}

Nowadays, credit societies are only of historical relevance. While their operation continued in the period of the Second Polish Republic, they vanished forever from Poland in the wake of the banking reform implemented in $1948{ }^{40}$ In the period of the Third Polish Republic, pursuant to the Act of 29 August 1997 on covered bonds and mortgage banks, long-term mortgage lending institutions were reinstated, but using the legal formula of mortgage banking.

\footnotetext{
${ }^{36}$ S. PIĘTKA and I. ZAWADZKI, Towarzystwo Kredytowe M. Warszawy i jego rola w zabudowie i rozwoju stolicy w ciagi 60-ciu lat (Warszawa: Druk L. Bruś, 1931), 16.

${ }^{37}$ J. RutKowsKi, Historia gospodarcza Polski, vol. 2, Czasy porozbiorowe do 1918 roku (Poznań: Księgarnia Akademicka, 1950), 232.

${ }^{38}$ Kempner, Dzieje gospodarcze Polski porozbiorowej. Dzieło zbiorowe pod kierunkiem S.A. Kempnera (Warszawa: Druk K. Kowalewskiego, 1920), 1:223.

${ }^{39}$ Ibid., 222.

${ }^{40}$ PAPIEŻ, Bankowość hipoteczna, 50, 52.
} 
Unlike credit societies, which were associations of debtors with no own capital and had the aim to clear debts, banks as "creditor organisations" have their own capital, from which they grant long-term mortgage-backed loans, not in covered bonds, but in cash. Whereas issuance of covered bonds, based on those mortgages, were used to refinance the lending activity of a bank. ${ }^{41}$ As a result of the specialisation of mortgage banks, their banking activities are generally limited to granting mortgage-backed loans and issuance of covered bonds in order to raise funds to finance their lending activity. ${ }^{42}$

However, the lending model offered by mortgage banks operating in Poland turned out to be barely competitive. ${ }^{43}$ There are currently three mortgage banks in operation: PKO Bank Hipoteczny, mBank Hipoteczny and Pekao Bank Hipoteczny, but the Banking Supervision Commission is receiving further applications for the establishment of mortgage banks, a phenomenon which illustrates a visible revival of this banking sector. ${ }^{44}$ The covered bonds they issue have so far had a symbolic share in the value of housing loans granted in Poland. The reason for this should be seen in the unrivalled offer of commercial (universal) banks in the field of mortgage loans and in the restrictive security rules of the real estate financing process used by mortgage banks. They result from the fact that covered bonds secured by a mortgage bank's receivables on mortgage loans granted need to have an optimal security level. Therefore, mortgage banks granted loans up to about $70 \%$ of the value of the real property, which is subject to a very conservative valuation, while the offer of universal banks envisaged loans exceeding the value of the property by as much as $20 \%$. This also excluded mortgage banks from financing buildings under construction and cooperative premises. ${ }^{45}$

At present, banks are granting fewer and fewer housing loans and mortgage banks are beginning to hedge their place on the financial market. Created by universal banks, they are becoming a specialized segment offering mortgage loans, which according to forecasts are much cheaper than those of universal banks. In addition, the issue of covered bonds is increasing significantly. 2016 was a record-breaking year of mortgage banking from the point of view of covered bond issue. Already mid-year, the issue amounted to 1.53

\footnotetext{
${ }^{41}$ KANIGOWSKI, Bank hipoteczny, 40-41.

${ }^{42}$ PAPIEŻ, Bankowość hipoteczna, 72.

${ }^{43}$ Raport $z$ prac, 16.

${ }^{44}$ See the introductory notes to this Article.

${ }^{45}$ Raport z prac, $16-17$.
} 
billion PLN, that is more than in the entire 2015 (1.48 billion). ${ }^{46}$ The most active issuer of covered bonds is PKO Bank Hipoteczny, which is the leader on the Polish market in terms of covered bond issue. At the end of March 2017, the value of issued and outstanding covered bonds payable to this bank amounted to 5.36 billion PLN. ${ }^{47}$

We should be hopeful that mortgage banking is coming back to favour. From a historical perspective, it seems that the mortgage banks restored in 1997 did not at all meet the real needs of the market. The simple dependence was forgotten: first needs are to be identified and then the potential establishment of an institution to meet them should be considered, as was done in the nineteenth century, noting the need for debt relief through credit societies. In the Third Polish Republic, the aim was to fuel the development of housing construction through cheap mortgage loans granted on real estate under construction, where there was no room for mortgage banks with their prudential lending procedures.

\section{BIBLIOGRAPHY}

SOURCES OF LAW

Dekret z dnia 25 października 1948 r. o reformie bankowej [Decree of 25 October 1948 on bank reform]. Journal of Laws No. 36, item 279.

Dekret z dnia 25 października 1948 r. o zasadach i trybie likwidacji niektórych przedsiębiorstw bankowych [Decree of 25 October 1948 on the rules and procedure for dissolving certain banking undertakings]. Journal of Laws No. 52, item 410.

Dekret z dnia 25 października 1948 r. o zasadach i trybie likwidacji niektórych instytucji kredytu długoterminowego [Decree of 25 October 1948 on the rules and procedure for dissolving certain long-term loan institutions]. Journal of Laws No. 52, item 411].

Prawo o przywilejach i hipotekach z dnia 1/13 czerwca $1825 \mathrm{r}$. [Law on privileges and mortgages of 1/13 June 1825]. Dziennik Praw Królestwa Polskiego [Journal of Laws of the Kingdom of Poland] of 1825, No. 40, pp. 355-373.

Prawo o ustaleniu własności dóbr nieruchomych, o przywilejach i hipotekach w miejsce tytułu XVIII księgi III Kodeksu Cywilnego z dnia 14/26 kwietnia 1818 r. [Law on the determination of the ownership of immovable property, privileges and mortgage in place of Title XVIII of Book III of the Civil Code of 14/26 April 1818]. Dziennik Praw Królewstwa Polskiego of 1817, No. 21, pp. 293-387.

\footnotetext{
${ }^{46}$ M. RUDKE, "Rekordowy rok polskich banków hipotecznych," Rzeczpospolita, June 30, 2016, accessed June 29, 2017, http://www.rp.pl/article/20160630/EKO/306309858.

${ }^{47}$ PKO BANK HiPOTECZnY, PKO Bank Hipoteczny liderem rynku listów zastawnych w Polsce, accessed June 29, 2017, http://www.pkobh.pl/ o-banku/aktualnosci/pko-bank-hipoteczny-lideremrynku-listow-zastawnych-w-polsce.
} 
Ustawa Towarzystwa Kredytowego miasta Lublina z dnia 25 czerwca / 7 lipca 1885 r. [Charter of the Lublin Credit Society of 25 June 1885 / 7 July 1885]. In Zbiór Praw. Postanowienia i rozporzqdzenia rząu w guberniach Królestwa Polskiego obowiąujące, wydane po zniesieniu w $1871 \mathrm{r}$. urzędowego wydania Dziennika Praw Królestwa Polskiego, vol. 29, part 3, pp. 227-301.

Ustawa warszawskiego towarzystwa kredytowego miejskiego z dnia 31 grudnia 1869 r. / 12 stycznia 1870 r. [Charter of the Warsaw Municipal Credit Society of 31 December 1869 / 12 January 1870]. Dziennik Praw Królestwa Polskiego of 1870, No. 240, pp. 5-61.

Ustawa z dnia 29 sierpnia 1997 r. o listach zastawnych i bankach hipotecznych [Act of 29 August 1997 on covered bonds and mortgage banks]. Journal of Laws of 2016, item 1771.

Zmiana statutu Towarzystwa Kredytowego miasta Lublina [Revised charter of the Lublin Municipal Credit Society]. Sobranije Uzakonienij i Rasporiażenij Prawitielstwa izdawajemoje pri Prawitielstwujuszczem Senatie of 1893, No. 60, Part 1, p. 525.

\section{LITERATURE}

[NO AUTHOR]. "ING Bank Śląski złożył do KNF wniosek ws. utworzenia banku hipotecznego." Accessed June 25, 2017. http://biznes.onet.pl/gielda/wiadomosci/ing-bank-slaski-zlozyl-doknf-wniosek-ws-utworzenia-banku-hipotecznego/m3j7ml.

BALZER, Oswald. "Hipoteka w dawnym ustawodawstwie polskim.” Gazeta Sąowa Warszawska 29 (1888): 475-81.

BARDZKI, Artur. Towarzystwa Kredytowe Miejskie, cz. I. Powstanie i rozwój. Warszawa: Druk Noskowskiego, 1912.

BARDZKI, Artur. Towarzystwa Kredytowe Miejskie, cz. II. Ustawa. Warszawa: Druk Noskowskiego, 1911.

BratKowski, Stefan: “Zwycięski spisek bankrutów.” Wiedza i Życie 9 (1996). Accessed June 27, 2017. http:// archiwum.wiz.pl/1996/96092400.asp.

Doвosiewicz, Zbigniew. Kredyty i gwarancje bankowe. Warszawa: Polskie Wydawnictwo Ekonomiczne, 2007.

Fermus-Bовоwiec, Anna. "Problem 'kwaterunku' lokali mieszkalnych w ustawodawstwie i nauce Polski Ludowej." Zeszyty Naukowe Uniwersytetu Przyrodniczo-Humanistycznego w Siedlcach 31 (2015): 49-70.

Fermus-BobowIEC, Anna: Towarzystwo Kredytowe miasta Lublina (1885-1915). Lublin: Wydawnictwo Uniwersytetu Marii Curie-Skłodowskiej, 2010.

Fermus-Boвowiec, Anna. "Z problematyki najmu lokali mieszkalnych w Polsce Ludowej." Z Dziejów Prawa 7 (2014): 257-78.

GĄSowska, Agnieszka. Bankowość hipoteczna. Warszawa: Poltext, 2000.

Hube, Karol. O instytucji hipotecznej w Królestwie Polskim. Warszawa: Drukarnia Gazety Polskiej, 1869.

JĘDRZYŃSKI, Jarosław. "Bankowość hipoteczna w Polsce. Czy wreszcie ruszy z miejsca?" Accessed June 25, 2017. https://rynekpierwotny.pl/wiadomosci-eszkaniowe/bankowosc- hipotecznaw-polsce-czy-wreszcie-ruszy-z-miejsca/3528.

Józefowicz, Ksawery. Przepisy o hipotekach, czyli wykład prawa hipotecznego w Królestwie Polskim obowiązującego. Warszawa: Druk Orgelbranda synów, 1873.

KANIGOWSKI, Krzysztof. Bank hipoteczny a rynek nieruchomości. Warszawa: Twigger, 2001. 
KARWOWSKI, Władysław: “Towarzystwo Kredytowe miasta Lublina.” In Dla sierot. Książa zbiorowa wydana staraniem Lubelskiego Towarzystwa Dobroczynności, 80-81. Warszawa, 1897.

Kaszubski, Remigiusz W., and Marcin Olszak. Bank hipoteczny. Zagadnienia prawne. Warszawa: Difin, 2000.

KemPNer, Stanisław Aleksander, ed. Dzieje gospodarcze Polski porozbiorowej w zarysie: dzieto zbiorowe. Vol. 1. Warszawa: Druk K. Kowalewskiego, 1920.

Korobowicz, Artur, and Wojciech WiTKOwsKi. Historia ustroju i prawa polskiego (1772-1918). Warszawa: Wolters Kluwer Polska, 2012.

PAPIEŻ, Renata. "Bankowość hipoteczna w Polsce. Czy wreszcie ruszy z miejsca?" Accessed June 25, 2017. https:// rynekpierwotny.pl/wiadomosci-mieszkaniowe/bankowosc-hipotecznaw-polsce-czy-wreszcie-ruszy-z-miejsca/3528.

PAPIEŻ, Renata. Bankowość hipoteczna w Polsce. Kraków: Oficyna Wydawnicza Text, 2004.

PIETRAsik, Adam, and Andrzej LASKOwSKI. Historia i wspótczesność dtugoterminowego kredytu hipotecznego w Polsce. Warszawa: Wydawnictwo Twigger, 2001.

Pietrasik, Adam, and Robert RyKowski. Hipoteczny list zastawny, Kraków: Kantor Wydawniczy Zakamycze, 2000.

PiętKA, S., and I. ZawAdzKI. Towarzystwo Kredytowe M. Warszawy i jego rola w zabudowie i rozwoju stolicy w ciagu 60-ciu lat. Warszawa: Druk L. Bruś, 1931.

PKO BANK HiPOTECZNY. "PKO Bank Hipoteczny liderem rynku listów zastawnych w Polsce." Accessed June 29, 2017. http://www.pkobh.pl/o-banku/aktualnosci/pko-bank-hipotecznyliderem-rynku-listow-zastawnych-w-polsce.

RAKOwIECKI, Bronisław. "Stulecie Ustawy sejmowej Hipotecznej 1818 r." Gazeta Sąowa Warszawska 30 (1918): 287-88.

RUDKE, Maciej. "Polski rynek listów zastawnych urośnie.” Rzeczpospolita, November 11, 2016. Accessed June 25, 2017. http://www.rp.pl/Wywiady/311079886-Polski-rynek-listow-zastawnychurosnie.html\#ap-1.

RUDKE, Maciej. "Rekordowy rok polskich banków hipotecznych.” Rzeczpospolita, June 30, 2016. Accessed June 29, 2017. http://www.rp.pl/article/20160630/EKO/306309858.

RutKowsksi, Jan. Historia gospodarcza Polski. Vol. 2, Czasy porozbiorowe do 1918 roku. Poznań: Księgarnia Akademicka, 1950.

Sobolewski, Piotr. "To już piąty bank hipoteczny w Polsce." Accessed June 25, 2017. http://www.rp.pl/artykul /1193183-To-juz-piaty-bank-hipoteczny-w-Polsce.html\#ap-1.

URZĄD KomisJi NADZORU BANKOWEGO. Raport z prac Grupy ds. emisji listów zastawnych przez banki. 2013.

WĄsowicz, Marek. "Instytucje kredytu długoterminowego na ziemiach polskich: rozwiązania rodzime, czy recepcja obcych wzorów?" In Wielokulturowość Polskiego Pogranicza. Ludzie -Idee-Prawo, edited by Adam Lityński and Piotr Fiedorczyk, 93-103. Białystok: Wydawnictwo Uniwersytetu w Białymstoku, 2003.

WójciKiewicz, Włodzimierz. Prawo hipoteczne Królestwa Polskiego. Wrocław-Warszawa-Kraków: Zakład Narodowy im. Ossolińskich, 1967.

ZALEwSKI, Stanisław. Ewolucja kredytu dtugoterminowego ziemskiego w Polsce. Warszawa: Instytut Wydawniczy „Biblioteka Polska”, 1938. 
ZuBELEwICZ, Floryan A. O papierach publicznych w ogólności ze szczegótowym opisem papierów krajowych, ważniejszych zagranicznych i instytucji, które na ich handel wptywaja. Warszawa: druk przy ul. Rymarskiej, 1843.

\section{MUNICIPAL MORTGAGE LOAN INSTITUTIONS IN THE KINGDOM OF POLAND. A CONTRIBUTION TO THE DISCUSSION ON THE ORGANISATIOAL MODEL OF MORTGAGE CREDIT IN POLAND}

\section{Summary}

The article presents the legal underpinnings of the operation of municipal credit societies in the Kingdom of Poland, which were institutions providing municipal mortgage loans. This is presented using the example of the Lublin Land Credit Society, and the author draws general conclusions about the model of mortgage loan offered by loan societies. At that time, the credit society was the most popular organisational model used with mortgage loans, not only in towns (municipal credit societies) but also in the countryside (land credit societies).

Furthermore, when seeking the origins of mortgage banking, the author presents other institutions granting long-term loans in the Polish territories, apart from credit societies. This analysis, with its legal and historical perspective, is considered by the author to be a contribution to discussion on mortgage loan and the place of contemporary mortgage banking in Poland.

Key words: mortgage; mortgage loan; loan society; mortgage bank; Kingdom of Poland.

\section{Translated by Tomasz Pałkowski}

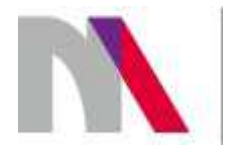

The preparation of the English version of Roczniki Nauk Prawnych (Annals of Iuridical Sciences) and its publication in electronic databases was financed under contract no. 836/PDUN/2018 from the resources of the Minister of Science and Higher Education for the popularization of science. 